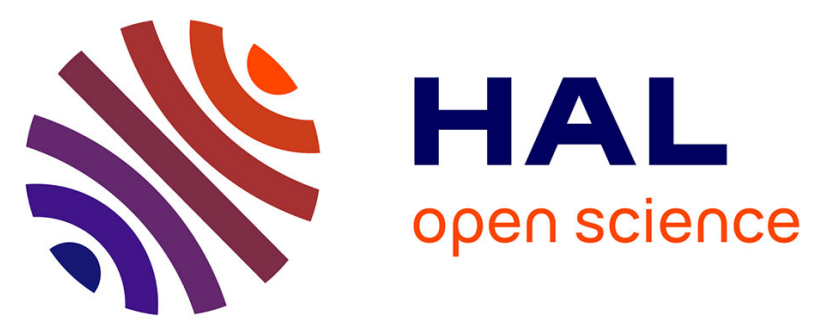

\title{
The rs3834129 polymorphism and breast cancer risk in mutation carriers
}

\author{
Irene Catucci, Paolo Verderio, Sara Pizzamiglio, Siranoush Manoukian, \\ Bernard Peissel, Daniela Zaffaroni, Gaia Roversi, Carla B. Ripamonti, \\ Barbara Pasini, Monica Barile, et al.
}

\section{To cite this version:}

Irene Catucci, Paolo Verderio, Sara Pizzamiglio, Siranoush Manoukian, Bernard Peissel, et al.. The rs3834129 polymorphism and breast cancer risk in mutation carriers. Breast Cancer Research and Treatment, 2010, 125 (3), pp.855-860. 10.1007/s10549-010-1068-8 . hal-00561320

\section{HAL Id: hal-00561320 \\ https://hal.science/hal-00561320}

Submitted on 1 Feb 2011

HAL is a multi-disciplinary open access archive for the deposit and dissemination of scientific research documents, whether they are published or not. The documents may come from teaching and research institutions in France or abroad, or from public or private research centers.
L'archive ouverte pluridisciplinaire HAL, est destinée au dépôt et à la diffusion de documents scientifiques de niveau recherche, publiés ou non, émanant des établissements d'enseignement et de recherche français ou étrangers, des laboratoires publics ou privés. 


\section{The CASP8 rs3834129 polymorphism and breast cancer risk in BRCA1 mutation carriers.}

Irene Catucci ${ }^{1,2,12}$, Paolo Verderio ${ }^{3,12}$, Sara Pizzamiglio ${ }^{3,12}$, Siranoush Manoukian ${ }^{4}$, Bernard Peissel ${ }^{4}$, Daniela Zaffaroni ${ }^{4}$, Gaia Roversi ${ }^{4}$, Carla B. Ripamonti ${ }^{2}$, Barbara Pasini ${ }^{5}$, Monica Barile ${ }^{6}$, Alessandra Viel ${ }^{7}$, Giuseppe Giannini ${ }^{8}$, Laura Papi ${ }^{9}$, Liliana Varesco ${ }^{10}$, Aline Martayan ${ }^{11}$, Mirko Riboni ${ }^{1}$, Sara Volorio ${ }^{1}$, Paolo Radice ${ }^{1,2 \star}$, Paolo Peterlongo ${ }^{1,2}$.

${ }^{1}$ IFOM, Fondazione Istituto FIRC di Oncologia Molecolare, Milan, Italy.

${ }^{2}$ Unit of Genetic Susceptibility to Cancer, Department of Experimental Oncology and Molecular Medicine, Fondazione IRCCS Istituto Nazionale dei Tumori, Milan, Italy.

${ }^{3}$ Unit of Medical Statistics and Biometry, Fondazione IRCCS Istituto Nazionale dei Tumori, Milan, Italy.

${ }^{4}$ Unit of Medical Genetics, Department of Preventive and Predictive Medicine, Fondazione IRCCS Istituto Nazionale dei Tumori, Milan, Italy.

${ }^{5}$ Department of Genetics, Biology and Biochemistry, University of Torino, Turin, Italy.

${ }^{6}$ Division of Cancer Prevention and Genetics, Istituto Europeo di Oncologia, Milan, Italy.

${ }^{7}$ Unit of Experimental Oncology 1, Centro di Riferimento Oncologico, IRCCS, Aviano, Italy

${ }^{8}$ Department of Experimental Medicine Sapienza University of Rome, Rome, Italy ${ }^{9}$ Medical Genetics Unit, Department of Clinical Physiopathology, University of Florence, Florence, Italy.

${ }^{10}$ Unit of Hereditary Cancers, Istituto Nazionale per la Ricerca sul Cancro, Genoa, Italy.

${ }^{11}$ Laboratory of Immunology, Regina Elena Cancer Institute, Rome, Italy

${ }^{12}$ These authors contributed equally to this work.

${ }^{*}$ Correspondence to Paolo Radice. Unit of Molecular Bases of Genetic Risk and Genetic Testing, Department of Preventive and Predictive Medicine, Fondazione IRCCS Istituto Nazionale dei Tumori, Milan, Italy. E-mail:

paolo.radice@istitutotumori.mi.it. Telephone: +39 02.2390.3224. Fax: +39 02.2390 .2764 


\section{Abstract}

Purpose. The rs3834129 polymorphism, in the promoter of CASP8 gene, has been recently reported as associated with breast cancer risk in the general population, with the minor allele del having a protective effect. Some of the genetic variants found associated with breast cancer risk were reported as risk modifiers in individuals with mutations in BRCA1 and BRCA2 genes. Here, we tested the effect of the rs3834129 del allele on breast cancer risk in BRCA mutation carriers. Methods. The rs3834129 was genotyped in a total of 1,207 Italian female $B R C A$ mutation carriers. Of these, 740 carried a $B R C A 1$ mutation and 467 a BRCA2 mutation. Overall, 699 were affected with breast cancer and 508 were unaffected. Results. When considering class 1 (loss-of-function) BRCA mutations, hazard ratios estimated by weighted multivariable Cox regression model, for individuals with at least one copy of the del allele, were 1.46 (95\% confidence interval $(\mathrm{Cl}): 1.081 .99)$ for $B R C A 1$ and $B R C A 2$ mutation carriers combined, 1.74 (95\% Cl: 1.242 .46$)$ for BRCA1 mutation carriers, and 1.09 (95\% $\mathrm{Cl}: 0.661 .80)$ for $B R C A 2$ mutation carriers. Conclusions. These results suggest that the minor allele del of rs3834129 is associated under a dominant model with increased breast cancer risk in carriers of $B R C A 1$ mutations but not in carriers of BRCA2 mutations.

\section{Keywords}

Breast cancer risk; CASP8; rs3834129; polymorphism; BRCA mutation carriers. 


\section{Introduction}

Caspases are apical positive mediators of apoptosis. Apoptosis is a key process in maintaining cell proliferation and controlling cancer development. For this reason, germ-line variations of caspase encoding genes have been studied with respect to cancer risk. The common polymorphism rs3834129, consisting of a six-nucleotide (AGTAAG) insertion/deletion in the promoter of the CASP8 gene at nucleotides 657_652, has been recently investigated in association with breast cancer risk. The first study, carried out in unselected Chinese breast cancer cases, suggested that the minor allele del (also referred to as $6526 \mathrm{~N}$ del) is protective versus breast cancer, with an odds ratio (OR) of heterozygotes 0.65 (95\% confidence interval, $\mathrm{Cl}: 0.540 .78$ ) and the OR of homozygotes for the del allele 0.50 (95\% Cl: 0.340 .74$)$ [1]. These findings, however, were not confirmed in each of three subsequent studies in Caucasian unselected breast cancer cases and controls [2-4]. We performed a fourth study in Italian familial breast cancer cases with no mutations in BRCA genes. This study indicated a lack of association between rs3834129 and breast cancer risk, but a case-only analysis showed a significant increasing trend for the del/del genotype frequency with later age of breast cancer diagnosis [5]. More recently, two concomitant meta-analyses corroborated the protective effect of the del allele versus breast cancer risk. The first was based on the four above- mentioned studies and estimated for the del allele carriers an overall OR of 0.94 of borderline significance (95\% Cl: 0.8841 .008$)$. This analysis pointed out that each of the single studies was probably statistically underpowered to detect the protective effect [6]. The second meta-analysis combined three different case-control series, and the ORs for the heterozygous and for the homozygotes for the del allele were 0.95 (95\% Cl: 083 1.08) and 0.82 (95\% Cl: 070 0.95), respectively [7]. Thus, it appears that in the general population the rs3834129 polymorphism is associated with breast cancer risk and that the minor allele del is acting as a protective factor. 
It has been shown that most of the genetic variants associated with breast cancer risk identified in the general population by genome-wide association studies are also modifiers of breast cancer risk in carriers of mutations in BRCA1 or BRCA2 genes $[8,9]$. In the present study, we investigated if the rs3834129 polymorphism modifies breast cancer risk testing a large series of Italian female carriers of mutations in BRCA genes.

\section{Material and Methods}

Study populations

BRCA gene mutation carriers were originally recruited at 8 different cancer genetic clinics participating in the Consorzio degli Studi Italiani sul Tumore Ereditario alla Mammella (CONSIT TEAM; Consortium of Italian Studies on Hereditary Breast Cancer). The CONSIT TEAM was established in 2009 as a national initiative to identify and study genetic modifiers of breast cancer risk and as a collaborative group to studies promoted by the Consortium of Investigators of Modifiers of BRCA1/2 (CIMBA) [10]. Eligibility criteria for the CONSIT TEAM were those adopted by CIMBA. All individuals included in this study were female carriers of a mutation in either $B R C A 1$ or $B R C A 2$, classified as a deleterious according to widely recognized criteria (Breast Cancer Information Core, http://research.nhgri.nih.gov/bic/). All individuals were enrolled at host institutions under research or clinical protocols approved by the local Ethic Committees and were $\geq 18$ years old at recruitment. Clinical information collected included data of birth, BRCA mutation description and type (according to functional effect), age at last follow-up, age at breast or ovarian cancer diagnosis, and age at bilateral prophylactic mastectomy. Related individuals were identified by a unique family identifier. 
Genotyping

Genotyping of rs3834129 was performed at Consortium for Genomic Technologies (Cogentech), Milan by direct sequencing (primer sequences and PCR protocol are available upon request). Deviation from Hardy-Weinberg equilibrium (HWE) was evaluated as a quality-control check in single individuals randomly selected from each family using Pearson chi-squared test.

\section{Statistical analysis}

The association of rs3834129 with breast cancer risk was assessed by estimating hazard ratios ( $\mathrm{HR}$ ) and their corresponding $95 \% \mathrm{Cl}$ using weighted multivariable Cox proportional hazards regression with robust estimates of variance, by clustering the observations on the family identity number. This approach allowed correcting for the bias in $\mathrm{HR}$ and variance estimates related to the fact that $B R C A 1$ and $B R C A 2$ mutation carriers are not randomly sampled with respect to their disease status and that they could belong to the same family. A detailed description of this approach has been published elsewhere $[11,12]$. Individuals were classified according to their age at the first of the following events: breast cancer diagnosis, ovarian cancer diagnosis, bilateral prophylactic mastectomy or last observation. Only individuals censored at breast cancer diagnosis were considered affected, while the other were considered unaffected. Weights were assigned separately for $B R C A 1$ and $B R C A 2$ mutation carriers according to their disease status and by age interval $(<25,25-29,30-34$, $35-39,40-44,45-49,50-54,55-59,60-64,65-69,>70$ years), such that the weighted observed incidences in the sample agree with established estimates for mutation carriers [13].

We considered log-additive, dominant and "three genotypes" models. Additional covariates included in each model were: center at which BRCA mutation carriers were ascertained and year of birth, as previously reported (11). 
The latter, grouped in 5 classes (<1940, 1940-1949, 1950-1959, 1960-1969, 1970), was included to account for possible cohort effect. We evaluated the goodness of fit of the data to the different models by using the Akaike's information criterion (AIC) [14]. All statistical analyses were performed with the SAS software (Version 9.2.; SAS Institute Inc. Cary, NC).

\section{Results}

Overall 1,241 BRCA1 and BRCA2 mutation carriers were contributed by the collaborating centers (Table 1). Genotyping failed for 18 samples. Thirteen women who self-reported as "non-Caucasian" and 3 women who carried mutations in both $B R C A 1$ and $B R C A 2$ were excluded from the study. Thus, 1,207 individuals remained included. Of these, 740 carried a BRCA1 mutation and 467 a $B R C A 2$ mutation. These individuals were censored at the age of the first of the following events: breast cancer diagnosis $(n=699)$, last observation $(n=318)$, ovarian cancer diagnosis $(n=173)$, and bilateral prophylactic mastectomy $(n=$ 17).

Genotypic frequencies of rs3834129 and weighted multivariable Cox model results are shown in Table 2. The genotypic frequencies were consistent with Hardy-Weinberg equilibrium. There was evidence for association with breast cancer risk for $B R C A 1$ mutation carriers but not for $B R C A 2$ mutation carriers. Each copy of the minor allele del conferred an HR of 1.23 (95\% Cl: 1.021 .49$)$ and of 0.92 (95\% Cl: 0.661 .29$)$ in the two groups, respectively. However, by resorting to a "three genotypes" model, the estimated risk for heterozygotes was higher than the estimated risk for homozygotes for the risk allele del, suggesting that its effect was not consistent with a log-additive model. Using the AIC as overall measure of the goodness of fit of the data to different models, the dominant model was selected. Under this parsimonious model, the HR for carriers with at least one copy of the del allele was $1.52(95 \% \mathrm{Cl}: 1.142 .02)$ for 
BRCA1 mutation carriers, and 1.35 (95\% Cl: 1.041 .76$)$ for $B R C A 1$ and $B R C A 2$ mutation carriers combined.

We pursued with an additional analysis and classified BRCA mutation according to their expected functional effects. Mutations of class 1 were those potentially causing loss-of-function and thus haplo-insufficiency; mutations of class 2 those potentially causing stable mutant protein with possible dominant negative effect [9]. Mutations were classified as of class 1 or class 2 as indicated in the database available to CIMBA collaborating groups at the CIMBA web site (http://www.srl.cam.ac.uk/consortia/cimba/members/login.html). Carriers of class 1 mutations were approximately $68 \%$ in $B R C A 1$ mutation carriers and approximately $89 \%$ in $B R C A 2$ mutation carriers. Genotypic frequencies of rs3834129 and weighted multivariable Cox model results for carriers of class 1 mutations are shown in Table 3. The number of class 2 mutation carriers was too small to justify separate analysis. Again, the dominant model resulted the most appropriate, and HR individuals with at least one copy of the del allele was 1.74 (95\% Cl: 1.242 .46$)$ for BRCA1 mutation carriers, and 1.46 (95\% Cl: 1.081 .99$)$ for $B R C A 1$ and $B R C A 2$ mutation carriers combined.

\section{Discussion}

Our study showed that the del allele of the rs3834129 polymorphism increases breast cancer risk in $B R C A 1$ mutation carriers indicating an opposite effect with respect to that observed in the general population. This apparent discrepancy could be explained by the different pathological characteristics of breast cancers arising in women from the general population (and in BRCA2 mutation carriers) compared to those of BRCA1-associated cancers. In fact, while the majority of $B R C A 1$ breast cancers have a basal-like phenotype clinically identified as the absence of estrogen receptor (ER), progesterone receptor (PR) and HER2 protein expression (so-called "triple negative") - 
cancers of the general population and of $B R C A 2$ mutation carriers are often ERpositive and PR-positive. Moreover, BRCA1 cancers, in contrast with sporadic ones, are high-grade and highly proliferative, have a higher frequency of TP53 somatic mutations, and are associated with poor prognosis [reviewed in 15]. It has been shown that susceptibility alleles at different loci, including FGFR2, TNRC9, 5p12, 2q35 and 8q24, are associated with a significant increased risk for ER-positive breast cancers, but have no or a significantly smaller effect on ERnegative breast cancer risk [16]. This indicates that genetic factors can be differentially associated with the risk for specific breast cancer subtypes. Consistently, a few single nucleotide polymorphisms (SNPs) identified in the general population as breast cancer low-penetrance alleles have been shown to increase breast cancer risk in $B R C A 2$, but not $B R C A 1$ mutation carriers [8,9].

To our knowledge, this is the first report of a breast cancer associated allele with opposite effect in the general population compared to BRCA1 mutation carriers. Further analyses are necessary to confirm the association of the rs3834129 del allele with breast cancer ER status and to verify if this association, that we observed in Italian at risk women, is present also in other populations. It has been shown that the del allele destroys a binding element in the CASP8 promoter for the stimulatory protein 1 (Sp1) and causes a reduced expression of the caspase-8 protein that decreases apoptosis of antitumor T lymphocytes [1]. Consequently, it was postulated that this could affect antitumor immune response and ultimately decrease cancer susceptibility. On the other hand, BRCA1associated breast cancers show an increased proliferation activity, as measured by mitotic count, significantly higher than that observed in sporadic cancers and in cancers from BRCA2 mutation carriers [17]. Thus, it might be speculated that in individuals who are particularly prone to develop highly replicating tumors a reduced apoptosis response leads to a less efficient mechanism of control of cancer progression and to increased risk.

In conclusion, our study suggested that rs3834129 is a risk modifier in $B R C A 1$ mutation carriers. In particular, the del allele is associated with an 
increased breast cancer risk under a dominant model. Moreover, the risk increase appeared to be higher in carrier of mutations causing haploinsufficiency.

\section{Ackowledgements}

We thank all patients and families who participated to this study, for providing samples and clinical data. We wish to thank Sue Healey, Lesley McGuffog and Olga Sinilnikova for allowing access to the classification of BRCA1 and BRCA2 mutations. This study was funded by grants from Fondazione Italiana per la Ricerca sul Cancro (Special Project "Hereditary tumors"), Associazione Italiana per la Ricerca sul Cancro (4017), Ministero della Salute (RFPS-2006-3-340203; Extraordinary National Cancer Program 2006, "Alleanza contro il Cancro"; "Progetto Tumori Femminili), Ministero dell'Universita' e Ricerca (RBLAO3-BETH), Istituto Superiore di Sanita` (526D/41), Lega Italiana per la Lotta contro i Tumori (progetto 02/12/R/47) and by funds from Italian citizens who allocated the $5 \times 1000$ share of their tax payment in support of the Fondazione IRCCS Istituto Nazionale Tumori, according to Italian laws (INTInstitutional strategic projects ' $5 \times 1000$ ').

\section{References}

1. Sun T, Gao Y, Tan W, Ma S, Shi Y, Yao J, Guo Y, Yang M, Zhang X, Zhang Q, Zeng C, Lin D (2007) A six-nucleotide insertion-deletion polymorphism in the CASP8 promoter is associated with susceptibility to multiple cancers. Nat Genet 39:605 613

2. Frank B, Rigas SH, Bermejo JL, Wiestler M, Wagner K, Hemminki K, Reed MW, Sutter C, Wappenschmidt B, Balasubramanian SP, Meindl A, Kiechle M, Bugert P, Schmutzler RK, Bartram CR, Justenhoven C, Ko YD, Brüning T, Brauch H, Hamann U, Pharoah PP, Dunning AM, Pooley KA, Easton DF, Cox A, Burwinkel B (2008) The CASP8 -652 6N del promoter polymorphism and breast cancer risk: a multicenter study. Breast Cancer Res Treat 111:139 144 
3. Cybulski C, Wokołorczyk D, Gliniewicz B, Sikorski A, Górski B, Jakubowska A, Huzarski T, Byrski T, Debniak T, Gronwald J, Lubiński J, Narod SA (2008) A six-nucleotide deletion in the CASP8 promoter is not associated with a susceptibility to breast and prostate cancers in the Polish population. Breast Cancer Res Treat 112:367 368

4. Haiman CA, Garcia RR, Kolonel LN, Henderson BE, Wu AH, Le Marchand L. (2008) Promoter polymorphism in the CASP8 gene is not associated with cancer risk. Nat Genet 40:259 260

5. De Vecchi G, Verderio P, Pizzamiglio S, Manoukian S, Barile M, Fortuzzi S, Ravagnani F, Pierotti MA, Radice P, Peterlongo P (2009) Evidences for association of the CASP8 $-6526 \mathrm{~N}$ del promoter polymorphism with age at diagnosis in familial breast cancer cases. Breast Cancer Res Treat 113:607 608

6. Sergentanis TN, Economopoulos KP (2009) Association of two CASP8 polymorphisms with breast cancer risk: a meta-analysis. Breast Cancer Res Treat. doi:10.1007/s10549-009-0471 5

7. Shephard ND, Abo R, Rigas SH, Frank B, Lin WY, Brock IW, Shippen A, Balasubramanian SP, Reed MW, Bartram CR, Meindl A, Schmutzler RK, Engel C, Burwinkel B, Cannon-Albright LA, Allen-Brady K, Camp NJ, Cox A (2009) A breast cancer risk haplotype in the caspase-8 gene. Cancer Res 69:2724 2728

8. Antoniou AC, Spurdle AB, Sinilnikova OM, Healey S, Pooley KA, Schmutzler RK, Versmold B, Engel C, Meindl A, Arnold N, Hofmann W, Sutter C, Niederacher D, Deissler H, Caldes T, Kämpjärvi K, Nevanlinna $\mathrm{H}$, Simard J, Beesley J, Chen X; Kathleen Cuningham Consortium for Research into Familial Breast Cancer, Neuhausen SL, Rebbeck TR, Wagner T, Lynch HT, Isaacs C, Weitzel J, Ganz PA, Daly MB, Tomlinson G, Olopade OI, Blum JL, Couch FJ, Peterlongo P, Manoukian S, Barile M, Radice P, Szabo Cl, Pereira LH, Greene MH, Rennert G, Lejbkowicz F, Barnett-Griness O, Andrulis IL, Ozcelik H; OCGN, Gerdes AM, Caligo MA, Laitman Y, Kaufman B, Milgrom R, Friedman E; Swedish BRCA1 and BRCA2 study collaborators, Domchek SM, Nathanson KL, Osorio A, Llort G, Milne RL, Benítez J, Hamann U, Hogervorst FB, Manders P, Ligtenberg MJ, van den Ouweland AM; DNA-HEBON collaborators, Peock S, Cook M, Platte R, Evans DG, Eeles R, Pichert G, Chu C, Eccles D, Davidson R, Douglas F; EMBRACE, Godwin AK, Barjhoux L, Mazoyer S, Sobol H, Bourdon V, Eisinger F, Chompret A, Capoulade C, Bressac-de Paillerets B, Lenoir GM, Gauthier-Villars M, Houdayer C, Stoppa-Lyonnet D; GEMO, Chenevix-Trench G, Easton DF, CIMBA (2008) Common 
breast cancer-predisposition alleles are associated with breast cancer risk in BRCA1 and BRCA2 mutation carriers. Am J Hum Genet 82:937 948

9. Antoniou AC, Sinilnikova OM, McGuffog L, Healey S, Nevanlinna $\mathrm{H}$, Heikkinen T, Simard J, Spurdle AB, Beesley J, Chen X; Kathleen Cuningham Foundation Consortium for Research into Familial Breast Cancer, Neuhausen SL, Ding YC, Couch FJ, Wang X, Fredericksen Z, Peterlongo P, Peissel B, Bonanni B, Viel A, Bernard L, Radice P, Szabo $\mathrm{Cl}$, Foretova L, Zikan M, Claes K, Greene MH, Mai PL, Rennert G, Lejbkowicz F, Andrulis IL, Ozcelik H, Glendon G; OCGN, Gerdes AM, Thomassen M, Sunde L, Caligo MA, Laitman Y, Kontorovich T, Cohen S, Kaufman B, Dagan E, Baruch RG, Friedman E, Harbst K, BarbanyBustinza G, Rantala J, Ehrencrona H, Karlsson P, Domchek SM, Nathanson KL, Osorio A, Blanco I, Lasa A, Benítez J, Hamann U, Hogervorst FB, Rookus MA, Collee JM, Devilee P, Ligtenberg MJ, van der Luijt RB, Aalfs CM, Waisfisz Q, Wijnen J, van Roozendaal CE; HEBON, Peock S, Cook M, Frost D, Oliver C, Platte R, Evans DG, Lalloo F, Eeles R, Izatt L, Davidson R, Chu C, Eccles D, Cole T, Hodgson S; EMBRACE, Godwin AK, Stoppa-Lyonnet D, Buecher B, Léoné M, Bressac-de Paillerets B, Remenieras A, Caron O, Lenoir GM, Sevenet N, Longy M, Ferrer SF, Prieur F; GEMO, Goldgar D, Miron A, John EM, Buys SS, Daly MB, Hopper JL, Terry MB, Yassin Y; Breast Cancer Family Registry, Singer C, Gschwantler-Kaulich D, Staudigl C, Hansen TO, Barkardottir RB, Kirchhoff T, Pal P, Kosarin K, Offit K, Piedmonte M, Rodriguez GC, Wakeley K, Boggess JF, Basil J, Schwartz PE, Blank SV, Toland AE, Montagna M, Casella C, Imyanitov EN, Allavena A, Schmutzler RK, Versmold B, Engel C, Meindl A, Ditsch N, Arnold N, Niederacher D, Deissler H, Fiebig B, Suttner C, Schönbuchner I, Gadzicki D, Caldes T, de la Hoya M, Pooley KA, Easton DF, Chenevix-Trench G, CIMBA. (2009) Common variants in LSP1, 2q35 and 8q24 and breast cancer risk for BRCA1 and BRCA2 mutation carriers. Hum Mol Genet 18:4442 4456

10. Chenevix-Trench G, Milne RL, Antoniou AC, Couch FJ, Easton DF, Goldgar DE, CIMBA (2007) An international initiative to identify genetic modifiers of cancer risk in BRCA1 and BRCA2 mutation carriers: the Consortium of Investigators of Modifiers of BRCA1 and BRCA2 (CIMBA). Breast Cancer Res 9:104

11. Osorio A, Milne RL, Pita G, Peterlongo P, Heikkinen T, Simard J, Chenevix-Trench G, Spurdle AB, Beesley J, Chen X, Healey S; KConFab, Neuhausen SL, Ding YC, Couch FJ, Wang X, Lindor N, Manoukian S, Barile M, Viel A, Tizzoni L, Szabo Cl, Foretova L, Zikan M, Claes K, Greene MH, Mai P, Rennert G, Lejbkowicz F, Barnett-Griness O, Andrulis IL, Ozcelik H, Weerasooriya N; OCGN, Gerdes AM, Thomassen M, Cruger DG, Caligo MA, Friedman E, Kaufman B, Laitman Y, Cohen S, Kontorovich T, Gershoni-Baruch R, Dagan E, Jernström H, Askmalm MS, 
Arver B, Malmer B; SWE-BRCA, Domchek SM, Nathanson KL, Brunet J, Ramón Y Cajal T, Yannoukakos D, Hamann U; HEBON, Hogervorst FB, Verhoef S, Gómez García EB, Wijnen JT, van den Ouweland A;

EMBRACE, Easton DF, Peock S, Cook M, Oliver CT, Frost D, Luccarini C, Evans DG, Lalloo F, Eeles R, Pichert G, Cook J, Hodgson S, Morrison PJ, Douglas F, Godwin AK; GEMO, Sinilnikova OM, Barjhoux L, StoppaLyonnet D, Moncoutier V, Giraud S, Cassini C, Olivier-Faivre L, Révillion F, Peyrat JP, Muller D, Fricker JP, Lynch HT, John EM, Buys S, Daly M, Hopper JL, Terry MB, Miron A, Yassin Y, Goldgar D; Breast Cancer Family Registry, Singer CF, Gschwantler-Kaulich D, Pfeiler G, Spiess AC, Hansen TV, Johannsson OT, Kirchhoff T, Offit K, Kosarin K, Piedmonte M, Rodriguez GC, Wakeley K, Boggess JF, Basil J, Schwartz PE, Blank SV, Toland AE, Montagna M, Casella C, Imyanitov EN, Allavena A, Schmutzler RK, Versmold B, Engel C, Meindl A, Ditsch N, Arnold N, Niederacher D, Deissler H, Fiebig B, Varon-Mateeva R, Schaefer D, Froster UG, Caldes T, de la Hoya M, McGuffog L, Antoniou AC, Nevanlinna H, Radice P, Benítez J, CMBA (2009). Evaluation of a candidate breast cancer associated SNP in ERCC4 as a risk modifier in BRCA1 and BRCA2 mutation carriers. Results from the Consortium of Investigators of Modifiers of BRCA1/BRCA2 (CIMBA). Br J Cancer 101:2048 54

12. Antoniou AC, Goldgar DE, Andrieu N, Chang-Claude J, Brohet R, Rookus MA, Easton DF (2005) A weighted cohort approach for analysing factors modifying disease risks in carriers of high-risk susceptibility genes. Genet Epidemiol 29:111

13. Antoniou A, Pharoah PD, Narod S, Risch HA, Eyfjord JE, Hopper JL, Loman N, Olsson H, Johannsson O, Borg A, Pasini B, Radice P, Manoukian S, Eccles DM, Tang N, Olah E, Anton-Culver H, Warner E, Lubinski J, Gronwald J, Gorski B, Tulinius H, Thorlacius S, Eerola H, Nevanlinna H, Syrjakoski K, Kallioniemi OP, Thompson D, Evans C, Peto J, Lalloo F, Evans DG, Easton DF (2003) Average risks of breast and ovarian cancer associated with BRCA1 or BRCA2 mutations detected in case Series unselected for family history: a combined analysis of 22 studies. Am J Hum Genet 72:1117 1130

14. Lee ET, Wang JW (2003) Tests of Goodness of Fit and Distribution Selection. In: Statistical methods for survival data analysis, $3^{\text {rd }}$ edn. John Wiley \& Sons, Inc. New Jersey, pp 221242

15. Palacios J, Robles-Frías MJ, Castilla MA, López-García MA, Benítez J (2008) The molecular pathology of hereditary breast cancer. Pathobiology. 75:85 94 
16. Garcia-Closas M, Chanock S (2008) Genetic susceptibility loci for breast cancer by estrogen receptor status. Clin Cancer Res 14:8000 8009

17. Lakhani SR, Jacquemier J, Sloane JP, Gusterson BA, Anderson TJ, van de Vijver MJ, Farid LM, Venter D, Antoniou A, Storfer-Isser A, Smyth E, Steel CM, Haites N, Scott RJ, Goldgar D, Neuhausen S, Daly PA, Ormiston W, McManus R, Scherneck S, Ponder BA, Ford D, Peto J, Stoppa-Lyonnet D, Bignon YJ, Struewing JP, Spurr NK, Bishop DT, Klijn JG, Devilee P, Cornelisse CJ, Lasset C, Lenoir G, Barkardottir RB, Egilsson V, Hamann U, Chang-Claude J, Sobol H, Weber B, Stratton MR, Easton DF (1998) Multifactorial analysis of differences between sporadic breast cancers and cancers involving BRCA1 and BRCA2 mutations. J Natl Cancer Inst 90:1138 1145 


\section{Tables}

TABLE 1. List of centers participating to CONSIT TEAM with numbers of BRCA1 and BRCA2 mutation carriers contributed. Mutation analysis in BRCA1 and BRCA2 was done at the center at which the samples were recruited with the exception of samples from Istituto Nazionale Tumori and European Institute of Oncology that were tested at Consortium for Genomic Technologies (Cogentech) Milan.

\begin{tabular}{lccc}
\hline \multicolumn{1}{c}{ Center } & $\begin{array}{c}\text { BRCA1 } \\
\text { mutation } \\
\text { carriers }\end{array}$ & $\begin{array}{c}\text { BRCA2 } \\
\text { mutation } \\
\text { carriers }\end{array}$ & $\begin{array}{c}\text { Total of } \\
\text { carriers (\%) }\end{array}$ \\
\hline Fondazione IRCCS Istituto Nazionale dei Tumori, Milano & 349 & 152 & $501(40.4)$ \\
Dip. di Genetica, Biologia e Biochimica, Universita di Torino & 100 & 69 & $169(13.6)$ \\
Istituto Europeo di Oncologia, Milano & 95 & 73 & $168(13.5)$ \\
Centro Riferimento Oncologico, Aviano & 52 & 66 & $118(9.5)$ \\
Dip. di Medicina Sperimentale, Sapienza Universita' di Roma & 61 & 44 & $105(8.5)$ \\
Sezione di Genetica Medica, Universita' di Firenze & 59 & 30 & $89(7.2)$ \\
Istituto Nazionale per la Ricerca sul Cancro, Genova & 37 & 24 & $61(4.9)$ \\
Laboratorio di Immunologia, Istituto Nazionale Tumori, Roma & 14 & 16 & $30(2.4)$ \\
All & 767 & 474 & $1,241(100)$ \\
\hline
\end{tabular}


TABLE 2. Genotype frequencies of rs3834129 by BRCA mutation and disease status, and hazard ratio estimates in all carriers of $B R C A$ mutations.

\begin{tabular}{|c|c|c|c|c|c|c|}
\hline$B R C A$ group & Genotype & $\begin{array}{l}\text { Unaffected } \\
(\%)\end{array}$ & $\begin{array}{l}\text { Affected } \\
(\%)\end{array}$ & $H R^{a}$ & $95 \% \mathrm{Cl}^{\mathrm{b}}$ & $P$-value \\
\hline $\begin{array}{l}B R C A 1 \text { and } \\
B R C A 2 \\
(\mathrm{~N}=1,207)\end{array}$ & $\begin{array}{l}\text { nor/nor } \\
\text { nor/del } \\
\text { del/del } \\
\text { del vs nor (per allele) } \\
\text { Dominant (del) }\end{array}$ & $\begin{array}{l}177(34.8) \\
224(44.1) \\
107(21.1)\end{array}$ & $\begin{array}{l}208(29.8) \\
346(49.5) \\
145(20.7)\end{array}$ & $\begin{array}{l}1.00 \\
1.40 \\
1.26 \\
1.15 \\
1.35 \\
\end{array}$ & $\begin{array}{l}1.06-1.85 \\
0.90-1.77 \\
0.96-1.38 \\
1.04-1.76 \\
\end{array}$ & $\begin{array}{l}0.018 \\
0.176 \\
0.121 \\
0.023\end{array}$ \\
\hline $\begin{array}{l}B R C A 1 \\
(\mathrm{~N}=740)\end{array}$ & $\begin{array}{l}\text { nor/nor } \\
\text { nor/del } \\
\text { del/del } \\
\text { del vs nor (per allele) } \\
\text { Dominant (del) }\end{array}$ & $\begin{array}{c}125(35.5) \\
152(43.2) \\
75(21.3)\end{array}$ & $\begin{array}{c}105(27.1) \\
193(49.7) \\
90(23.2)\end{array}$ & $\begin{array}{l}1.00 \\
1.56 \\
1.42 \\
1.23 \\
1.52 \\
\end{array}$ & $\begin{array}{l}1.16-2.13 \\
1.00-2.03 \\
1.02-1.49 \\
1.14-2.02 \\
\end{array}$ & $\begin{array}{l}0.003 \\
0.052 \\
0.033 \\
0.004 \\
\end{array}$ \\
\hline $\begin{array}{l}B R C A 2 \\
(\mathrm{~N}=467)\end{array}$ & $\begin{array}{l}\text { nor/nor } \\
\text { nor/del } \\
\text { del/del } \\
\text { del vs nor (per allele) } \\
\text { Dominant (del) }\end{array}$ & $\begin{array}{l}52(33.3) \\
72(46.2) \\
32(20.5)\end{array}$ & $\begin{array}{c}103(33.1) \\
153(49.2) \\
55(17.7)\end{array}$ & $\begin{array}{l}1.00 \\
1.09 \\
0.80 \\
0.92 \\
1.00\end{array}$ & $\begin{array}{l}0.66-1.78 \\
0.42-1.55 \\
0.66-1.29 \\
0.62-1.60\end{array}$ & $\begin{array}{l}0.746 \\
0.516 \\
0.619 \\
0.988\end{array}$ \\
\hline
\end{tabular}

${ }^{a} \mathrm{HR}$, hazard ratio (adjusted for center and year of birth); ${ }^{b} \mathrm{Cl}$, confidence interval nor/nor, common homozygotes; nor/del, heterozygotes; del/del, rare homozygotes 
TABLE 3. Genotype frequencies of rs3834129 by BRCA mutation and disease status, and hazard ratio estimates in carriers of $B R C A$ loss-of-function (class 1) mutations.

\begin{tabular}{|c|c|c|c|c|c|c|}
\hline$B R C A$ group & Genotype & $\begin{array}{l}\text { Unaffected } \\
(\%)\end{array}$ & $\begin{array}{l}\text { Affected } \\
(\%)\end{array}$ & $H^{a}$ & $95 \% \mathrm{Cl}^{\mathrm{b}}$ & $P$-value \\
\hline $\begin{array}{l}B R C A 1 \text { and } \\
B R C A 2 \\
(\mathrm{~N}=920)\end{array}$ & $\begin{array}{l}\text { nor/nor } \\
\text { nor/del } \\
\text { del/del } \\
\text { del vs nor (per allele) } \\
\text { Dominant (del) }\end{array}$ & $\begin{array}{c}143(36.8) \\
165(42.4) \\
81(20.8)\end{array}$ & $\begin{array}{l}156(29.4) \\
265(49.9) \\
110(20.7)\end{array}$ & $\begin{array}{l}1.00 \\
1.56 \\
1.29 \\
1.18 \\
1.46\end{array}$ & $\begin{array}{l}1.12-2.15 \\
0.87-1.93 \\
0.95-1.46 \\
1.08-1.99 \\
\end{array}$ & $\begin{array}{l}0.008 \\
0.208 \\
0.138 \\
0.015\end{array}$ \\
\hline $\begin{array}{l}\text { BRCA1 } \\
(\mathrm{N}=504)\end{array}$ & $\begin{array}{l}\text { nor/nor } \\
\text { nor/del } \\
\text { del/del } \\
\text { del vs nor (per allele) } \\
\text { Dominant (del) }\end{array}$ & $\begin{array}{c}94(38.4) \\
100(40.8) \\
51(20.8)\end{array}$ & $\begin{array}{c}69(26.6) \\
128(49.4) \\
62(23.9)\end{array}$ & $\begin{array}{l}1.00 \\
1.83 \\
1.60 \\
1.33 \\
1.74 \\
\end{array}$ & $\begin{array}{l}1.27-2.64 \\
1.03-2.48 \\
1.05-1.69 \\
1.24-2.46 \\
\end{array}$ & $\begin{array}{l}0.001 \\
0.035 \\
0.019 \\
0.002 \\
\end{array}$ \\
\hline $\begin{array}{l}B R C A 2 \\
(\mathrm{~N}=416)\end{array}$ & $\begin{array}{l}\text { nor/nor } \\
\text { nor/del } \\
\text { del/del } \\
\text { del vs nor (per allele) } \\
\text { Dominant (del) }\end{array}$ & $\begin{array}{l}49(34.0) \\
65(45.1) \\
30(20.8)\end{array}$ & $\begin{array}{c}87(32.0) \\
137(50.4) \\
48(17.6)\end{array}$ & $\begin{array}{l}1.00 \\
1.24 \\
0.79 \\
0.92 \\
1.09\end{array}$ & $\begin{array}{l}0.73-2.10 \\
0.40-1.57 \\
0.65-1.32 \\
0.66-1.80\end{array}$ & $\begin{array}{l}0.419 \\
0.506 \\
0.662 \\
0.738\end{array}$ \\
\hline
\end{tabular}

${ }^{a} \mathrm{HR}$, hazard ratio (adjusted for center and year of birth); ${ }^{b} \mathrm{Cl}$, confidence interval nor/nor, common homozygotes; nor/del, heterozygotes; del/del, rare homozygotes 